\title{
Considering Jumping Ship? A Pirate Looks At Retirement
}

Bob G. Kilpatrick, Northern Arizona University, USA

\begin{abstract}
If you're like me, a "senior" faculty member at a public state university facing significant budget cuts, recently you've probably thought about leaving your current position for another faculty position in a different state. A possible reason for considering jumping ship is envisioning a clearer picture of your retirement as it nears on the horizon - a retirement that does not look quite what you had projected ten years ago, due to the that fact that you elected the defined contribution (DC) plan (often referred to as an "optional" or "alternate" retirement plan at universities) rather than the traditional defined benefit $(D B)$ state employee pension plan when you first arrived at your university 20-odd years ago (which was the right choice, at that time, given the information available...keep reminding yourself of that), and then seeing the value of that retirement account drop considerably two-three years ago. Although your retirement account may have mostly recovered, there are still those lost years of growth that may have you secondguessing your previous decision. Alas, that decision cannot be undone, but a new decision can be created by moving to another state. It is this possible decision that is the topic of this paper. What factors should be considered in choosing between the traditional DB plan and the optional DC plan for an individual who cannot necessarily reach the maximum benefit under the DB plan?
\end{abstract}

Keywords: faculty retirement; defined benefit; defined contribution; education funding

\section{BACKGROUND}

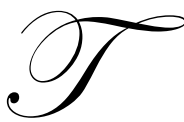

he basic difference between a traditional DB plan and a DC plan is in defining the university's commitment to the faculty retirement plan. The commitment under a DB plan is a monthly pension that typically begins at "full retirement age" as defined under the plan and continues for the retired faculty's life or over the joint lives of the retired faculty and designated beneficiary. Thus, the faculty assumes relatively little risk in a DB plan, as the university (technically, the state pension fund) guarantees the pension payments over the payment period. The university's commitment under a DC plan is to only make contributions based on a predetermined rate to the faculty's individual account. The amount available for the faculty's retirement is the accumulated balance in the account at his/her retirement date. Thus, the faculty assumes all risks that the investment's performance will provide sufficient funds over his/her retirement years. A second potentially significant difference concerns what will remains for beneficiaries after the faculty's death. When the retired faculty (and designated beneficiary under a joint annuity option) dies, all payments under a DB plan typically cease. Under a DC plan, however, any remaining balance becomes part of his/her estate and is thus available for distribution to heirs.

As a general rule, retirement planners advise toward DC plans because of the longer period over which earnings can accumulate and their portability. On the other hand, DB plans are recommended to clients if they do not begin funding their retirement plans until later ages. This reasoning is based on the fact that there is a shorter time for contributions in a DC plan to grow before reaching retirement age, whereas the maximum benefit that can be provided at retirement age can still be funded through a DB plan. However, these general rules are typically geared toward private sector funds, where the client has sufficient funds and control over the design of the plans. Certainly, such individual control is not available when joining an existing retirement plan in the public sector. 
Michel, et al. (2010) present an excellent analysis, on a state-by-state basis, of breakeven rates of returns at which faculty would be indifferent in choosing between a DB and a DC plan. In general, they develop annual rates of return that must be earned in the university's optional DC plan to equate the present value of the pension annuity under the state's DB plan. Their analysis is based on several assumptions, including an expected pension payout period of 25 years and a 3 percent discount rate used to calculate the DB plan payout, all of which are reasonable. However, one main assumption is that the decision point is 30 years until retirement age. This length of time yields two critical results - (1) 30 years of participation is more than sufficient to yield the maximum pension allowed every DB pension plan's annuity formula, and (2) it provides a long time period over which annual contributions in a DC plan can accumulate.

As indicated in the introductory paragraphs, this paper focuses on senior faculty considering whether to move to another state's university system in order to enroll in its DB plan. Because a senior faculty will not likely have 30 years remaining in his/her career, (1) the maximum pension under the DB plan formula may not be payable (an issue that is often misunderstood or overlooked), and (2) the significantly shorter time period over which to accumulate future contributions and earnings in a DC plan will mathematically cause a significant increase in the breakeven rates of return computed in the Michel, et al. study. For example, they compute a $6.46 \%$ annual required rate of return in Arizona's DC plan to equate to its DB plan benefit. However, reducing the faculty's remaining work period from 30 years to only 10 increases the required annual rate of return to $24.04 \%$. Additionally, their analysis fails to capture any differential in employee contribution rates under the plans.

\section{ADDITIONAL RETIREMENT PLAN CONSIDERATIONS FOR OLD PIRATES JUMPING SHIP}

Three additional major areas of focus in choosing between a DC plan and DB plan include: (1) the faculty's required contribution to the plans; (2) the university's commitment to the plan, i.e., its contribution rate under the DC plan or its pension formula under the DB plan; and (3) the faculty's age and years of credit in the plan.

Most, but not all, university DC and DB plans require faculty contributions based on some percentage of salary. However, these contribution rates are generally not the same under the different plans. Faculty contribution rates are normally fixed in DC plans and do not change over the faculty's worklife. Michel, et al. report the median faculty contribution rate for all states at $5 \%$, with a range of $0 \%$ to $13 \%$. Required faculty contribution rates under state DB plans are subject to change and usually reflect the overall fund's performance. For example, Arizona's DB plan faculty contribution rate will increase from $9.85 \%$ to $10.75 \%$ in July 2011, which is the third consecutive year of increased contribution rates (the 2006 rate was $9.1 \%$ ).

The university's commitment to a DC plan is simply its contribution to the faculty's individual account. Michel, et al. report the median university contribution rate for all states at $8.3 \%$, with a range of $2.5 \%$ to $13.3 \%$. The university commitment to a DB plan is to provide a pension annuity at full retirement age. This annuity is determined under the plan's stated formula, and is usually based on a combination of an annual accrual rate, a compensation measure, and years of credit in the plan (e.g., $1.5 \%$ of final three years average compensation, times years of participation in the plan).

The faculty's years of credit in the plan and expected age at retirement are critical inputs into the decision for two reasons. First, virtually all plans require some minimum number of years of participation in the plan for the faculty to vest in either (1) the university's contributions, including related earnings (DC plan), or (2) the pension annuity under the plan's formula. Faculty are always immediately vested in their own contributions and usually in the related earnings. A typical vesting provision is $100 \%$ vesting in employer contributions and earnings after five years of participation in the plan. Second, the annuity payments under DB plans are always determined upon the faculty's reaching full retirement age, as defined under the plan. This age does not necessarily coincide with the faculty's social security retirement age, and is subject to change for newly-hired employees. For example, Illinois, Missouri, and New Mexico recently changed their full retirement age for new hires to age 67. Many state DB plans also require some minimum years of participation to receive the full pension payment, regardless of age. Many also define retirement age based on the combination of years of participation and age (e.g., a sum of 80), although attainment of this measure is unlikely under the assumptions of this paper. Some state DB plans allow faculty to purchase years of service credits for prior work at other out-of-state public universities and/or military service. 
Contemporary Issues In Education Research - August 2011

Volume 4, Number 8

Table 1: University Retirement Plans In Arizona And New Mexico

\begin{tabular}{|c|c|c|c|c|}
\hline & \multicolumn{2}{|r|}{ Arizona } & \multicolumn{2}{|c|}{ New Mexico } \\
\hline & $\begin{array}{c}\text { Optional Retirement Plan } \\
\text { (DC Plan) }\end{array}$ & $\begin{array}{c}\text { Arizona State Retirement System } \\
\text { (DB Plan ) }\end{array}$ & $\begin{array}{c}\text { Alternative Retirement } \\
\text { Plan (DC Plan) }\end{array}$ & $\begin{array}{c}\text { Educational Retirement Act } \\
\text { (DB Plan) }\end{array}$ \\
\hline $\begin{array}{l}\text { Required faculty } \\
\text { contribution }\end{array}$ & $7 \%$ & $10.75 \%$ & $9.4 \%$ & $9.4 \%$ \\
\hline $\begin{array}{l}\text { Vesting in university's } \\
\text { contribution (DC) or } \\
\text { pension annuity (DB) }\end{array}$ & $\begin{array}{l}100 \% \text { after } 5 \text { years } \\
\text { (immediate if faculty enters } \\
\text { with an existing account } \\
\text { from another university's } \\
\text { retirement plan) }\end{array}$ & $\begin{array}{l}5-10 \text { year graded schedule } \\
(25 \% \text { after } 5 \text { years, } 40 \% \text { after } 6 \text { years, } \\
55 \% \text { after } 7 \text { years, } 70 \% \text { after } 8 \text { years, } \\
85 \% \text { after } 9 \text { years, } 100 \% \text { after } 10 \\
\text { years) }\end{array}$ & Immediate & $100 \%$ after 5 years \\
\hline $\begin{array}{l}\text { University contribution } \\
\text { (DC) or pension formula } \\
\text { (DB) }\end{array}$ & $7 \%$ & $\begin{array}{l}\text { Total years of credit } \mathrm{x} \\
\text { Multiplier } \mathrm{x} \\
\text { Average Compensation } \\
\text { (Multiplier ranges from } 2.1 \% \text { for }< \\
20 \text { years to } 2.3 \% \text { for } 30+\text { years) } \\
\text { (Average compensation = highest } 5 \\
\text { consecutive years in final } 10 \text { years) }\end{array}$ & $7.9 \%$ & $\begin{array}{l}\text { Total years of credit } \mathrm{x} \\
2.35 \% \mathrm{x} \\
\text { Average Compensation } \\
\text { (Average compensation = highest } 5 \\
\text { consecutive years) }\end{array}$ \\
\hline Full retirement age & $\mathrm{n} / \mathrm{a}$ & $\begin{array}{ll}\text { - } & \text { Age } 65 ; \text { or } \\
\text { - } & \text { Age } 62+10 \text { years of credit; or } \\
\text { - } & \text { Total years of credit }+ \text { age }=85\end{array}$ & $\mathrm{n} / \mathrm{a}$ & $\begin{array}{l}\text { - } 30 \text { years or credit; or } \\
\text { - } \quad \text { Age } 67+5 \text { years of credit; or } \\
\text { - } \quad \text { Total years of credit }+ \text { age }=80\end{array}$ \\
\hline $\begin{array}{l}\text { Reduction formula for early } \\
\text { retirement }\end{array}$ & $\mathrm{n} / \mathrm{a}$ & $\begin{array}{l}\text { Eligible if age } 50 \text { and } 5 \text { years of credit. } \\
\text { Each full retirement test has a } \\
\text { reduction formula, e.g., if under age } \\
65 \& 5-9 \text { years of credit, benefit is } \\
\text { reduced by } 3 \% \text { per year between ages } \\
60 \text { and } 65 \text {, and by } 5 \% \text { per year prior to } \\
\text { age } 60 \text {. }\end{array}$ & $\mathrm{n} / \mathrm{a}$ & $\begin{array}{l}\text { Rule of } 80 \text { requires minimum of age } \\
65 \text { for full benefit. Benefit is reduced } \\
\text { by } 2.4 \% \text { per year between ages } 60 \\
\text { and } 65 \text {, and } 7.2 \% \text { per year prior to } \\
\text { age } 60 .\end{array}$ \\
\hline
\end{tabular}




\section{A COMPARISON OF TWO STATES}

Table 1 compares relevant DB and DC plan features in the neighboring states of Arizona and New Mexico. (The author acknowledges that the choice of these two land-locked states represents a complete departure from the paper's previous nautical theme.) Following are some differences that should considered when performing calculations of required rates of returns to reach a break even between the types of plans -

1. The plans have differential required faculty contribution rates. For example, if an Arizona DC plan participant is comparing retirement balances with either of the New Mexico plans, the incremental 2.4\% contribution must be taken into account to make the results meaningful.

2. The vesting requirements under the plans differ. While both states' DC plans have immediate vesting (Arizona's requires the faculty to have participated in a plan through his/her previous university), the DB plans have different vesting schedules. Thus, for example, unless the faculty plans to participate for at least 10 years in Arizona's DB plan, the projected payout must be reduced to reflect the reduced vesting in the university's share.

3. The universities' contribution rates in their respective DC plans differ by more than $10 \%$, a definite advantage in New Mexico's system. Also, New Mexico's DB annual accrual rate is more favorable, as it provides a flat $2.35 \%$ annual accrual rate, where Arizona uses a discrete set of rates that varies based on blocks of years of credit in the plan. Note that both states allow faculty to purchase additional years credits to some extent, e.g., New Mexico allows for the purchase of up to 5 years of credit if the faculty was previously employed in another state's university or was in the military.) Average compensation is defined similarly in the two states' plans. (Arizona's 5-year reflects a change effective for hires after July 1, 2011, from the previous "higher of 3 - or 5-year average.")

4. In defining full retirement age for purposes of the DB plan annuity computation, some differences exist. Both use "Rule of X," where X equals the combination of years of credit plus age to reach full retirement age. (New Mexico's represents a change, effective for hires after July 1, 2010, from its previous Rule of 75. Arizona's represents a change, effective for hires after July 1, 2011, from its previous Rule of 80.) This type of criterion usually allows for early retirement (e.g., prior to social security retirement age) for faculty who have a long period of service at the university; thus, it is probably unlikely that the faculty described in this paper would meet that criterion. Both DB plans have an age plus years of credit for faculty who are hired at later ages, but note the rather significant difference between the two factors. Arizona's provision has a younger age but requires more years of credit (age 62 and 10 years) compared with New Mexico's older age with fewer years of credit (age 67 and 5 years). Finally, Arizona has an age-solely criterion in defining full retirement age, which is age 65, but it is important to not overlook Arizona's 10 -year vesting requirement to receive the full benefit, while New Mexico has a service-only criterion, which is 30 years.

\section{OTHER FINANCIAL CONSIDERATIONS BEYOND PLAN FEATURES}

As the Pew Center on the States reports in its ominously-titled The Trillion Dollar Gap (February 2010), many states currently face significant funding gaps in their state retirement systems. Indeed, in its follow-up report, the Pew Center notes (November 2010) that 18 states took action last year to reduce their promised pensions, by reducing benefits and/or increasing employee contributions. Indeed, Arizona and New Mexico made such changes, as reflected parenthetically in the previous section. Two years ago, 11 states made similar changes. Thus, the prudent person (or pirate, as the case may be) should make very sure that he/she has the most current information when evaluating the retirement plans associated with a job change, especially late in one's career. The Pew Center on the States website (www.pewcenteronthestates.org) is an excellent resource for obtaining current information on individual states' retirement plans, as well as individual state ratings on how well their plans are maintained. 


\section{ABOUT THE AUTHOR}

Bob G. Kilpatrick is a Professor of Accounting at The W. A. Franke College of Business at Northern Arizona University. Email: bob.kilpatrick@nau.edu.

\section{REFERENCES}

1. Michel, N., S. Lawrence, J. Lajaunie and S. Mauldin, A Comparison of Defined Benefit and Optional Retirement Plan Rates of Return in Higher Education, Journal of Retirement Planning, (March-April 2010, pp. 17-26).

2. The Pew Center on the States, The Trillion Dollar Gap, (February 2010), www.pewcenteronthestates.org.

3. The Pew Center on the States, Roads to Reform: Changes to Public Sector Retirement Benefits Across States, (November 2010), www.pewcenteronthestates.org. 
NOTES 